\title{
Synthesis of naringin 6"-ricinoleate using immobilized lipase
}

\author{
Verônica M Almeida ${ }^{1 \dagger}$, Carla RC Branco ${ }^{1 \dagger}$, Sandra A Assis ${ }^{2 \dagger}$, Ivo JC Vieira ${ }^{3 \dagger}$, Raimundo Braz-Filho ${ }^{3}$ and \\ Alexsandro Branco ${ }^{1 *+}$
}

\begin{abstract}
Background: Naringin is an important flavanone with several biological activities, including antioxidant action. However, this compound shows low solubility in lipophilic preparations, such as is used in the cosmetic and food industries. One way to solve this problem is to add fatty acids to the flavonoid sugar unit using immobilized lipase. However, there is limited research regarding hydroxylation of unsaturated fatty acids as an answer to the low solubility challenge. In this work, we describe the reaction of naringin with castor oil containing ricinoleic acid, castor oil's major fatty acid component, using immobilized lipase from Candida antarctica. Analysis of the ${ }^{1} \mathrm{H}$ and ${ }^{13}$ C NMR (1D and 2D) spectra and literature comparison were used to characterise the obtained acyl derivative.

Results: After allowing the reaction to continue for 120 hours (in acetone media, $50^{\circ} \mathrm{C}$ ), the major product obtained was naringin 6"-ricinoleate. In this reaction, either castor oil or pure ricinoleic acid was used as the acylating agent, providing a $33 \%$ or $24 \%$ yield, respectively. The chemical structure of naringin $6 "$-ricinoleate was determined using NMR analysis, including bidimensional (2D) experiments.
\end{abstract}

Conclusion: Using immobilized lipase from C. antarctica, the best conversion reaction was observed using castor oil containing ricinoleic acid as the acylating agent rather than an isolated fatty acid.Graphical abstract

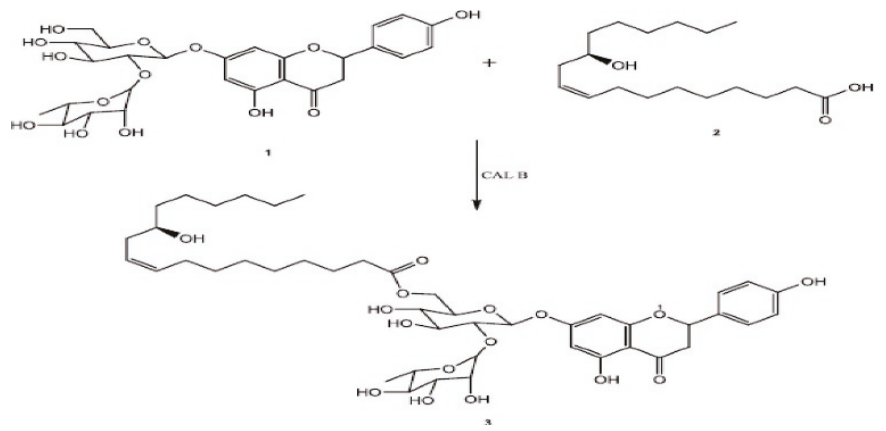

\section{Background}

Flavonoids are a class of natural products that occur in a large variety of plants, fruits and vegetables and can possess antimicrobial, antioxidant, antiviral, anti-platelet, antitumour, anti-inflammatory, anti-allergic, estrogenic,

\footnotetext{
* Correspondence: branco@uefs.br

+ Contributed equally

${ }^{1}$ Laboratório de Fitoquímica, Departamento de Saúde, Universidade Estadual de Feira de Santana, 44031460 Feira de Santana, BA, Brazil

Full list of author information is available at the end of the article
}

and radical-scavenging characteristics [1]. They exhibit a wide range of beneficial effects on various aspects of human health, including cardiovascular and chronic diseases as well as certain forms of cancer. It has been established that the beneficial properties of flavonoids are mostly attributed to their ability to scavenge free radicals, chelate metal ions, activate antioxidant enzymes or inhibit certain enzyme systems [2]. The antioxidant properties of flavonoids are due to the presence of phenol groups on the rings A and B. In addition to their 
importance as an antioxidant, flavonoids have gained attention in the production of industrial foods, cosmetics and pharmaceuticals [3]. However, the glycosylated flavonoids have rarely been used in these preparations due their low solubility in lipophilic preparations. The reaction of the sugar moiety in the flavanone nucleus with a fatty acid has been shown to be a good alternative for obtaining improved solubility, the stability in pharmaceutical applications [4-6]. The acylation of hydroxyls of flavonoids as a chemical strategy can furnish a mixture of products, which have shown different types of esterification due to a lack of regioselectivity in this method [7]. To circumvent the disadvantages of the conventional chemical process, the use of enzymes in non-aqueous medium has opened new avenues for obtaining products derived from natural antioxidants with high added value.

There are numerous advantages of employing enzymes as catalysts in organic solvents compared with in water, such as increased solubility of non polar substrates, shifting of thermodynamic equilibrium in favor of synthesis over hydrolysis, and elimination of microbial contamination in the reaction. Lipases are a few natural enzymes which are stable in the presence of organic solvents. Therefore, enzyme catalysis in organic solvents is being increasingly used for a variety of applications [8]. The use of enzymes confines acylation to the glycosidic moiety of the molecule, preventing changes to the flavonoid framework and preserving its biological activity $[9,10]$.

The acylation of flavonoid glycosides can be performed using different types of enzymes, such as subtilisin (protease from Bacillus subtilis), lipase from Candida antarctica and Pseudomonas cepacia, lipoprotein, carboxylesterases and even cell extracts. However, the lipase B immobilized from Candida antarctica seems to be the most versatile and regioselective enzyme for this reaction [11-14].

The enzymatic immobilization has some disadvantages as changes in enzyme kinetic behavior, decrease their residual activity, and modify the three dimensional structure by restricting the enzyme because the randomness of the enzyme-substrate interactions. However, these drawbacks are being circumvented by modern technology and the immobilization process offers advantages that outweigh these drawbacks $[12,14]$. This is because the immobilized enzyme increases stability of enzymes, so they are more resistant to changes in $\mathrm{pH}$ and heat treatment facilitates the removal and recovery of the enzyme after the reaction, and may even improve their synthesis activity in a medium with an organic solvent [13]. A good selection of an appropriate immobilization method is capable of high catalytic activity of lipases $[13,14]$.

The lipase B enzyme from C. antarctica (CAL B) has many advantages in a biotechnology setting because of its following characteristics: low cost, good stability in organic solvents, does not require co-factors, very wide $\mathrm{pH}$ operating range, works with various substrate types and is stereo-, chemo- and regioselective $[14,15]$.

CAL B is able to acylate flavonoids, specifically in its glycoside moiety, without affecting the flavonoid skeleton responsible for its antioxidant activity [16]. Among the most studied flavonoid glycosides are naringin and rutin. The former, in particular, is an interesting candidate for the acylation reaction because it has a primary hydroxyl group in the glycoside region, and primary alcohols are preferred sites for CAL B. Acylation reactions of naringin have been described by several papers, demonstrating its interest and viability [17-22].

Naringin (1) is a natural flavanone isolated principally from citric fruits, such as Citrus paradisi and Citrus aurantium peel [23]. This compound is industrially used in perfumes, beverages, sweeteners, stabilisers and vegetable oils in bakery products, principally due its antioxidant properties [24]. Naringin has shown anti-inflammatory, antioxidant [25], antimicrobial [26], antiviral [27], antiulcer [28], anticarcinogenic [29] and hypolipidemic [30] activity. Naringin may also protect vascular smooth muscle cells by increasing the strength and resistance of blood vessels, which reduces the atherogenic effects [31].

In the enzymatic lyophilisation of naringin, several fatty acids (saturated, unsaturated, substituted, dicarboxylic and aromatic acids) have been used as acylating agents [3]. Reactions comparing saturated and unsaturated fatty acids indicate better performance for the saturated fatty acids [22,32-34]. In this context, few studies describe the use of a hydroxy unsaturated fatty acid.

The castor oil is obtained from the seeds of Ricinus communis plant and has chemical characteristics atypical compared to most vegetable oils, as well as the presence of the triglyceride of ricinoleic acid, which fatty acid is a hydroxy uncommon in vegetable oils, it is present in the range $84-91 \%$ of its composition and to a lesser extent by oleic and linoleic fatty acids $(<5 \%)$, stearic and palmitic fatty acids $(<2 \%)$ [35]. Thus, the enzymatic acylation of naringin with castor oil tends to produce a major compound, the naringin 6 "-ricinoleate.

The objective of this work was to produce naringin 6 "-ricinoleate (3) through the reaction of naringin (1) with a hydroxy unsaturated fatty acid (ricinoleic acid) by direct esterification (2) and castor oil by transesterification reaction, using lipase (Figure 1).

\section{Results and discussion}

For the initial reaction step, esterification of naringin, under several conditions previously described in the literature that used fatty acids, were analysed $[10,18,20,22]$. Choosing the solvent, temperature, time and concentration of substrate are important steps to biocatalysis. The 


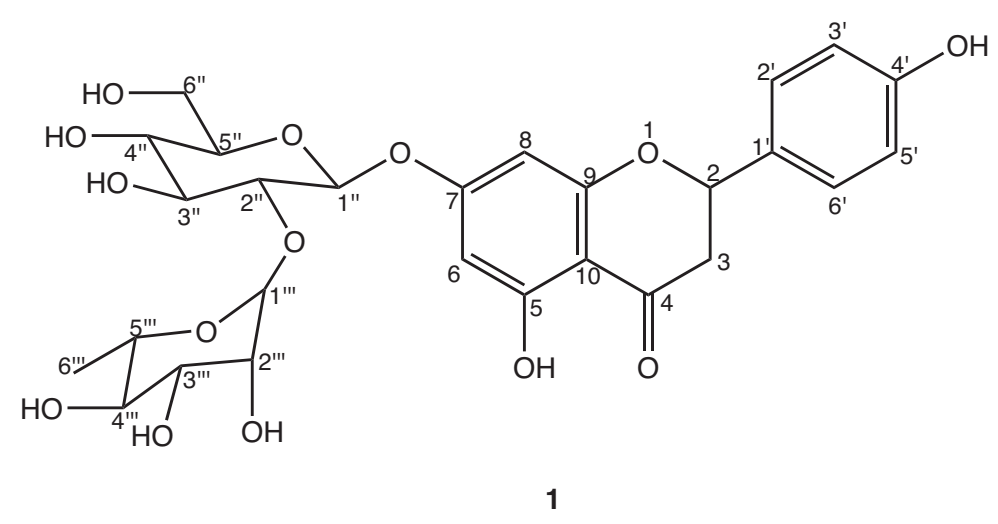



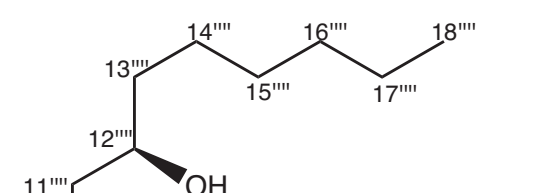<smiles>COC(=O)CCCC[CH-]CC[CH+]C=C(C)CO</smiles>

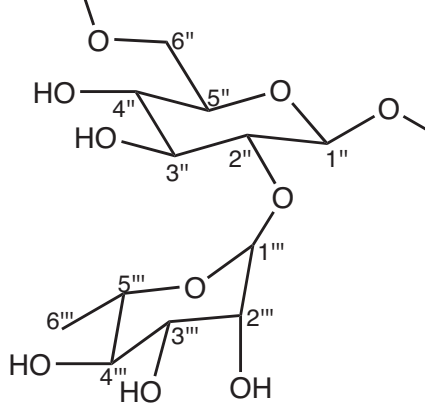<smiles>Cc1cc(O)c2c(c1)OC(c1ccc(O)cc1)CC2=O</smiles>

\section{3}

Figure 1 Lipase-catalyzed regioselective esterification of naringin (1) with ricinoleic acid (2).

polarity of the solvent is also an important parameter in the biocatalysis reaction due to its contribution to the solubility of glycosylated flavonoids (polar) in a fatty acid and lipase mixture $[36,37]$. Acetone and THF have shown good performance in this type of reaction [22]. The temperature can be used to influence the viscosity of the medium, which in turn influences the solubility of the substrates and products, enzyme activity and even 
denaturation of the biocatalyst [38]. The most efficient reaction using immobilized CAL B occurs at temperatures between 45 to $60^{\circ} \mathrm{C}[9,21]$. The molar ratio of reagents also influences the product yield; the amount of ester formed is controlled by the reaction balance, with the yield being governed by the limiting reagent when substrates are in excess [39]. Thus, in the acylation of flavonoids, it is common to have excess of the acylating agent (fatty acid) because of its low cost and high availability.

As mentioned above, the best possible reaction conditions for acylation of naringin using lipase include the following: using acetone as the solvent, operating at $50^{\circ} \mathrm{C}$ for 120 hours and using a ratio of 3 times (w/w) of acylating agent to naringin. Thus, the naringin was converted to naringin 6"-O-ricinoleate (3), using either a fatty acid or castor oil as the acylating agent, and no other esters were formed in this reaction. The conversion taxa of naringin were analysed by high performance liquid chromatography coupled with a diode array detector (HPLCDAD). Figure 2a shows the profile chromatogram of the reaction, and contains two peaks: naringin at $12.3 \mathrm{~min}$ and its ester formed (3) at $22.9 \mathrm{~min}$. Both peaks showed, in their respective UV spectra (Figure 2b), an intense absorption band at $280 \mathrm{~nm}$ and another band of lower intensity at $330 \mathrm{~nm}$. These bands are characteristic of flavonoids lacking unsaturation between $\mathrm{C}-2$ and $\mathrm{C}-3$ and, consequently, an absence of conjugation between rings $\mathrm{A}$ and B [40]. This observation confirms that esterification occurred in the glycoside region.

After 24 hours of incubation it was observed that naringin was significantly converted to naringin 6"-Oricinoleate (Figure 3). After allowing the reaction to proceed 120 hours in acetone at $50^{\circ} \mathrm{C}$, a $24 \%$ yield of esters was obtained when ricinoleic acid was used as acylating agent and a yield of approximately $33 \%$ was obtained when castor oil was the acylating agent.

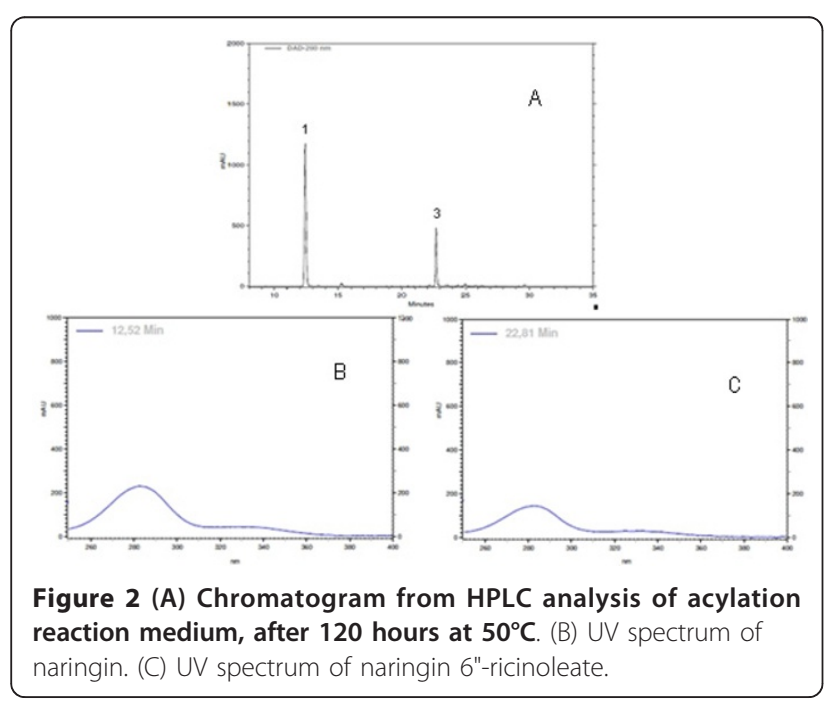



Figure 3 Synthesis of naringin 6"-ricinoleate by lipase.

The major product of reaction of naringin and castor oil was purificated by $\mathrm{SiO}_{2}$ open column chromatography and submitted to spectral analysis. The ${ }^{1} \mathrm{H}$ NMR spectrum confirmed the signals to flavonone skeleton due the chemical shifts at $\delta_{\mathrm{H}} 7.34(2 \mathrm{H}, \mathrm{d}, \mathrm{H}-2$ ' and H-6'), 6.80 (2H, d, H-3'and $\left.\mathrm{H}-5^{\prime}\right), 12.9$ (HO at $\left.\mathrm{CH}-5\right)$, $5.51\left(1 \mathrm{H}, \mathrm{t}, \mathrm{J}=12.8 \mathrm{~Hz}, \mathrm{H}-2_{\text {axial }}\right), 3.18\left(1 \mathrm{H}, \mathrm{m}, \mathrm{H}-3_{\mathrm{eq}}\right)$ and $2.73\left(1 \mathrm{H}, \mathrm{m}, \mathrm{H}-3_{\mathrm{ax}}\right)$. The correct position of esterification of ricinoleic acid in the glycosides moiety of naringin was deduced by ${ }^{13} \mathrm{C}$ NMR spectra $\left(\left\{{ }^{1} \mathrm{H}\right\}\right.$ - and APT). The comparison of the chemical shifts of the methylene $\mathrm{CH}_{2}-6$ " $\left[\Delta \delta_{\mathrm{C}}=+2.82=63.7\right.$ (3) - 60.88 (1), downfield shift $]$ and methine $\mathrm{CH}-5$ " $\left[\Delta \delta_{\mathrm{C}}=-3.31=\right.$ $77.53(\mathbf{1})-74.22(3), \gamma$ - effect protection] confirmed this deduction. Similar effects were also observed in other acyl-glycosilated naringin in the same position [19].

\section{Experimental}

\section{Enzyme and chemical}

The lipase used was immobilized lipase from C. antarctica recombinant in Aspergillus oryzae from Sigma-Aldrich ${ }^{\circledR}$. The naringin and molecular sieves ( $3 \AA$ ) were purchased from Sigma-Aldrich ${ }^{\circledR}$. The acetone used was purchased from Merck ${ }^{\circledR}$ and the castor oil was purchased from a local farmer of Feira de Santana (Natural Rural). The solvents used in high performance liquid chromatography are of analytic grade from Merck ${ }^{\circledR}$. A Milli-Q System ${ }^{\circledR}$ (Bedford, MA, USA) was used to purify the water. The reactions were performed in shaker flasks (model TE 424, TECNAL $\left.^{\circledR}\right)$.

\section{Equipment and chemical analysis}

NMR spectra were recorded in $\mathrm{CDCl}_{3}$ soln at $400 \mathrm{MHz}$ for ${ }^{1} \mathrm{H}$ and $120 \mathrm{MHz}$ for ${ }^{13} \mathrm{C}$ on a JEOL ${ }^{\circledR}$ Eclipse-400 
spectrometer, using TMS as an internal standard or by reference to the solvent signals: $\mathrm{CHCl}_{3}$ at $\delta_{\mathrm{H}} 7.25$ and $\mathrm{CHCl}_{3}$ at $\delta_{\mathrm{C}} 77.00$. The NMR spectra for each product were recorded in DMSO- $d_{6}$ soln at $500 \mathrm{MHz}$ for ${ }^{1} \mathrm{H}$ and $120 \mathrm{MHz}$ for ${ }^{13} \mathrm{C}$ on a Bruker ${ }^{\circledR}$ DRX-500 $\left({ }^{1} \mathrm{H}: 500\right.$ $\mathrm{MHz} ;{ }^{13} \mathrm{C}: 400 \mathrm{MHz}$ ) spectrometer, using TMS as an internal standard or by reference to the solvent signals: $\mathrm{CHCl}_{3}$ at $\delta_{\mathrm{H}} 7.25$ and $\mathrm{CHCl}_{3}$ at $\delta_{\mathrm{C}} 77.00$. HRGC analyses were recorded on a CG Shimadzu ${ }^{\circledR}$, model GC2010 gas chromatograph using a glass capillary column (Rtx-1: $30 \mathrm{~m} \times 0.25 \mathrm{~mm} \times 0.25 \mu \mathrm{m}$, Restek ${ }^{\circledR}$ ). For the GC analysis, hydrogen was used as the carrier gas, with a flow rate of $0.6 \mathrm{ml} / \mathrm{min}$; the injector port was set at $300^{\circ} \mathrm{C}$ and the flame ionisation detector (FID) at $300^{\circ} \mathrm{C}$. The temperature programmed for the analysis of 2 ranged from $120^{\circ} \mathrm{C}$ to $300^{\circ} \mathrm{C}\left(10^{\circ} \mathrm{C} / \mathrm{min}\right)$. For TLC analysis, a silica gel (Merck, Kieselgel 60) was used and spots were visualized using UV ( 254 and $360 \mathrm{~nm}$ ) and sulphuric acid solution (10\%) with after heating. The eluent used was $\mathrm{CHCl}_{3} / \mathrm{MeOH} / \mathrm{H}_{2} \mathrm{O}(8: 2: 0.3, \mathrm{v} / \mathrm{v} / \mathrm{v})$.

Analyses of high performance liquid chromatography was performed on a Merck-Hitachi liquid chromatograph LaChrom Elite ${ }^{\circledR}$ equipped with a VRW HITACHI L- 2130 pump, a VRW HITACHI L-2300 Diode-array detector (DAD), and an auto sampler with a $100 \mu \mathrm{L}$ loop. The data were acquired and processed using Ezchrom Elite software. The reaction product 3 was analysed using a reverse-phase HPLC column: Purospher ${ }^{\circledR}$ STAR RP-18e (250 $\mathrm{mm} \times 4,6 \mathrm{~mm}$ i.d., $5 \mu \mathrm{m}$ ) column (Merck). The mobile phase was composed of solvent (A) $\mathrm{H}_{2} \mathrm{O} / \mathrm{H}_{3} \mathrm{PO}_{4}$ $0.1 \%$ and solvent (B) $\mathrm{MeOH}$. The solvent gradient was composed of A (75-0\%) and B (25-100\%) for $20 \mathrm{~min}$, then $100 \% \mathrm{~B}$ for $4 \mathrm{~min}$, then again at the initial conditions $(75 \%$ $A$ and $25 \%$ B) for $10 \mathrm{~min}$. A flow rate of $1.0 \mathrm{~mL} / \mathrm{min}$ was used in a $30^{\circ} \mathrm{C}$ oven, and $20 \mu \mathrm{L}$ of each sample was injected. The procedure was repeated three times for each sample. Samples and mobile phases were filtered through a $0.22 \mu \mathrm{m}$ Millipore filter prior to HPLC injection. Spectra data were recorded from to 200 to $400 \mathrm{~nm}$ during the entire run.

\section{Obtaining of ricinoleic acid (2)}

Compound 2 was obtained by adding $100 \mathrm{~mL}$ of sodium hydroxide solution to $300 \mathrm{~mL}$ of castor oil. After 12 hours, the reaction was neutralised with hydrochloric acid and extracted with ethyl acetate (3 times). This reaction was investigated by HRGC after a silylation reaction with bis(trimethylsilyl)trifluoroacetamide [41].

\section{NMR data of naringin (1)}

${ }^{1} \mathrm{H}$ NMR: $\delta_{\mathrm{H}}(\mathrm{ppm}) 12.07$ (s, HO-5), 9.68 (s, HO-4'), 7.34 (m, H-2'/H-6'), 6.81 (m, H-3'/H-5'), 6.11 (m, H-8), 6.09 (m, H-6), 5.51 (m, H-2), $5.16\left(\mathrm{~m}, \mathrm{H}-1^{\prime \prime \prime}\right), 5.11(\mathrm{~m}$,
$\left.\mathrm{H}-1^{\prime \prime}\right), 3.70$ and $3.40\left(\mathrm{~m}, 2 \mathrm{H}-6^{\prime \prime}\right), 3.70\left(\mathrm{H}-5^{\prime \prime \prime}\right), 3.72(\mathrm{~m}$, H-5"), $3.70\left(\mathrm{H}-2^{\prime \prime \prime}\right), 3.50$ (m, H-3"), 3.35 (H-3"'), 3.30 (m, $\left.\mathrm{H}-4^{\prime \prime}\right), 3.20$ (m, H-2"), 3.25 (m, H4"'), 3.40 and 2.73 (m, 2H-3), $1.14\left(\mathrm{~m}, 3 \mathrm{H}-6^{\prime \prime \prime}\right) .{ }^{13} \mathrm{C}$ NMR: $\delta_{\mathrm{C}}(\mathrm{ppm}) 197.97$ (C4), 165.32 (C-7), 163.41 (C-5), 163.16 (C-9), 158.60 (C4'), 129.08 (CH-2'/CH-6'), $116.44\left(\mathrm{CH}-3^{\prime} / \mathrm{CH}-5^{\prime}\right), 103.70$ (C-10), $100.89\left(\mathrm{CH}-1^{\prime \prime}\right), 97.85\left(\mathrm{CH}-1^{\prime \prime \prime}\right), 96.77$ (CH-6), $95.58(\mathrm{CH}-8), 79.32(\mathrm{CH}-2), 77.59(\mathrm{CH}-3 "), 76.69(\mathrm{CH}-$ 2"), 77.53 (CH-5"), 72.27 (CH-4"'), 70.93 (CH-2"'), 70.85 (CH-3"'), 70.03 (CH-4"), $68.78\left(\mathrm{CH}-5^{\prime \prime \prime}\right), 60.88\left(\mathrm{CH}_{3}-6^{\prime \prime}\right)$, $42.49\left(\mathrm{CH}_{2}-3\right), 18.56\left(\mathrm{CH}_{3}-6^{\prime \prime \prime}\right)$.

\section{NMR data of ricinoleic acid (2)}

${ }^{1} \mathrm{H}$ NMR $\left(400 \mathrm{MHz}, \mathrm{CDCl}_{3}\right): \delta_{\mathrm{H}}(\mathrm{ppm}) 5.52(1 \mathrm{H}, \mathrm{m}, \mathrm{H}-$ 9'”'), 5.38 (1H, m, H-10'”'), 3.60 (1H, m, H-12'"'), $2.29(2 \mathrm{H}$, t, J = 6.4 Hz, H-2"'”), 2.19 (2H, m, H-11'”'), $2.01(2 \mathrm{H}, \mathrm{m}$, H-8'”'), 1.59 (2H, m, H-3'”'), 1.43 (2H, m, H-13'”'), 0.86 $\left(3 \mathrm{H}, \mathrm{t}, \mathrm{J}=5.9 \mathrm{~Hz}, \mathrm{H}-18^{\prime \prime \prime}\right)$ ), 1.26-1.39 (overlapped signals, the remaining chain $\mathrm{CH}_{2}$ groups signals). ${ }^{13} \mathrm{C}$ NMR (400 $\left.\mathrm{MHz}, \mathrm{CDCl}_{3}\right): \delta_{\mathrm{C}}(\mathrm{ppm}) 179.16$ (C-1'"'), 133.02 (CH-9'”'), $125.12(\mathrm{CH}-10$ '"', $\gamma$ - effect of the hydroxyl group at $\mathrm{CH}$ $\left.12^{\prime \prime \prime \prime)}\right)$, 71.64 ( $\left.\mathrm{CH}-12^{\prime \prime \prime \prime}\right), 36.60\left(\mathrm{CH}_{2}-13^{\prime \prime \prime \prime}\right), 35.10\left(\mathrm{CH}_{2}-\right.$ $11^{\prime \prime \prime \prime), ~} 34.13\left(\mathrm{CH}_{2}-2\right.$ '”'), $31.76\left(\mathrm{CH}_{2}-16\right.$ '”'), $27.25\left(\mathrm{CH}_{2}-8^{\prime \prime \prime \prime}\right.$, $\gamma$ - effect of the $\mathrm{CH}_{2}$-13'”, , cis-configuration), $25.57\left(\mathrm{CH}_{2}\right.$ 14 '”', $\gamma$ - effect of the hydroxyl group at $\mathrm{CH}-12$ '"'), 24.67 ( $\mathrm{CH}_{2}$-3'”', $\gamma$ - effect of the carbonyl group $\mathrm{C}-1$ '”'), 22.54 ( $\mathrm{CH}_{2}-17$ '”'), 13.98 ( $\left.\mathrm{CH}_{3}-18^{\prime \prime \prime \prime}\right)$, 29.42-28.9 (overlapped signals of the remaining chain $\mathrm{CH}_{2}$ groups).

\section{Enzymatic reactions}

\section{Drying conditions of reaction medium components}

The reaction components were dried using methods described in the literature [18]. The substrates (fatty acid and flavonoid) were dried under vacuum in desiccators with silica gel for one week. The acetone used in the reaction went through the drying process for 7 days with the addition of $100 \mathrm{gL}-1(10 \% \mathrm{w} / \mathrm{v})$ molecular sieve, previously dried at $150^{\circ} \mathrm{C}$ for 24 hours.

\section{Synthesis reaction of naringin 6"-ricinoleate (3)}

$500 \mathrm{mg}$ of immobilized lipase was added to the reaction mixture, which consisted of $0.7 \mathrm{~g}$ of naringin (1), $2.1 \mathrm{~g}$ of acyl agent (castor oil or ricinoleic acid) and $25 \mathrm{~mL}$ of acetone. Incubation was carried out at $50^{\circ} \mathrm{C}$ under agitation, in the presence of $500 \mathrm{mg}$ molecular sieves $(3 \AA)$. The reaction was followed by HPLC-DAD (Figure 2). A $0.2 \mathrm{~mL}$ aliquot of the reaction medium was removed at each sampling time $(24,48,72,96$ and 120 hours) and each sample was dried and re-suspended in $1 \mathrm{~mL}$ of HPLC grade methanol and filtered through a $0.22 \mu \mathrm{m}$ Millipore filter for subsequent analysis by HPLC-DAD. Quantitative analysis of naringin 6"-ricinoleate (3) was performed by HPLC as described by Mellou et al. [22]. 


\section{Purification of naringin 6"-ricinoleate (3)}

After the end of each reaction the enzyme was removed by filtration and the acetone evaporated at room temperature. Product 3 was purified using methodology described by Mellou et al, 2006, with some modifications [22]. The reaction product was submitted to fractionation in open column chromatography with silica gel $(60 \AA)$ and eluted with mixtures of organic solvents in crescent order of polarity.

\section{Statistical analysis}

Data were obtained in triplicate and expressed as mean and tested for significance by $P<0.05$. Then it was adopted the Tukey's test "post hoc". Both these tests showed significant differences between the means.

\section{NMR data of naringin 6"-ricinoleate (3)}

${ }^{1} \mathrm{H}$ NMR: $\delta_{\mathrm{H}}(\mathrm{ppm}) 12.09$ (s, HO-5), 9.78 (s, HO-4'), 7.34 (m, H-2'/H-6'), 6.80 (m, H-3'/H-5'), 6.14 (m, H-8), 6.07 (m, H-6), 5.52 (m, H-2), 5.21 (s, H-1"'), 5.12 (m, H1"), 4.35 (m, 2H-6", $\mathrm{CH}_{2}$-O-ricinolyl), 3.75-3.70 (m, H5", H-3"' and H-5"'), 3.49-3.40 (m, H-2", H-3", H-4", H2"'), 3.25 (m, H-4"'), 3.25, 2.70 (m, 2H-3) a, 1.19 (m, 3H6"'), 2.17-0.85 (fatty chain). ${ }^{13}$ C NMR: $\delta_{\mathrm{C}}$ (ppm) 198.70 (C-4), 173.27 ( $\mathrm{C}=\mathrm{O}$ ester), 166.70 (C-7), 165.24 (C-5), 163.71 (C-9), 158.46 (C-4'), 131.03 (CH-9'”'), 128.22 (CH-10'"', $\gamma$ - effect of the hydroxyl group), 128.2 (CH-2' and $\mathrm{CH}-6$ '), 115.67 (CH-3' and $\left.\mathrm{CH}-5^{\prime}\right), 104.00$ (C-10), 100.97 (CH-1"), 97.82 (CH-1"'), 96.8 (CH-6), 95.71 (CH8), 79.29 (CH-2), 77.35 (CH-3”), 76.65 (CH-2”), 74.22 (CH-5"), 72.28 (CH-4"'), 70.94 (CH-2"'), 70.63 (CH-3"'), 70.56 (CH-4"), 70.21 (CH-12"'” linked to $\mathrm{OH}), 68.81$ (CH-5"'), 63.70 (CH-6" acylated), $42.96\left(\mathrm{CH}_{2}-3\right), 36.93$ ( $\left.\mathrm{CH}_{2}-13^{\prime \prime \prime \prime)}\right)$ 35.64 ( $\left.\mathrm{CH}_{2}-11^{\prime \prime \prime \prime}\right), 34.35\left(\mathrm{CH}_{2}-2^{\prime \prime \prime \prime}\right), 31.84$ ( $\left.\mathrm{CH}_{2}-16^{\prime \prime \prime \prime}\right), 29.52\left(\mathrm{CH}_{2}-15^{\prime \prime \prime \prime}\right), 29.37-29.14\left(\mathrm{CH}_{2}-4\right.$ '”' to $\left.\mathrm{CH}_{2}-7^{\prime \prime \prime \prime)}\right), 27.32\left(\mathrm{CH}_{2}-8\right.$ "', $), 25.67\left(\mathrm{CH}_{2}-14, ",\right), 25.07$ ( $\mathrm{CH}_{2}-3$ '”'), 22.57 ( $\mathrm{CH}_{2}-17^{\prime \prime \prime \prime), ~} 18.3\left(\mathrm{CH}_{3}-6\right.$ '”, rhamnose), $14.49\left(\mathrm{CH}_{3}-18^{\prime \prime \prime}\right)$.

\section{Conclusions}

The esterification of naringin with castor oil or ricinoleic acid using $C$. antarctica lipase was obtained as anticipated. The major product obtained was characterized as naringin 6"-ricinoleate (3) and its structure was confirmed by $1 \mathrm{D}$ and $2 \mathrm{D}$ NMR analyses. This work examines the enzymatic acylation of flavonoids employing hydroxy unsaturated fatty acids. The best conversion reaction was observed using castor oil as source of acylating agent rather than isolated fatty acid.

\section{Acknowledgements}

We would like to thank the Fundação de Amparo a Pesquisa do Estado do Rio de Janeiro (FAPERJ, Rio de Janeiro, Brazil), Fundação de Amparo a Pesquisa do Estado da Bahia (FAPESB, Salvador, Brazil), Conselho Nacional de
Desenvolvimento Científico e Tecnológico (CNPq, Brazil), Fundação Universitária José Bonifácio (FUJB, UFRJ, Rio de Janeiro, Brazil) and PRONEX (Grant 4002, Brazil) for financial support.

\section{Author details}

${ }^{1}$ Laboratório de Fitoquímica, Departamento de Saúde, Universidade Estadual de Feira de Santana, 44031460 Feira de Santana, BA, Brazil. 'Laboratório de Enzimologia, Departamento de Saúde, Universidade Estadual de Feira de Santana, 44031460 Feira de Santana, BA, Brazil. ${ }^{3}$ Laboratório de Ciências Químicas, Universidade Estadual do Norte Fluminense Darcy Ribeiro, avenida Alberto Lamego 2000, Campos dos Goytacazes, Rio de Janeiro 28013-602, RJ, Brazil.

\section{Competing interests}

The authors declare that they have no competing interests.

Received: 23 January 2012 Accepted: 11 May 2012

Published: 11 May 2012

\section{References}

1. Harborne JB, Williams CA: Advances in favonoid research since 1992. Phytochemistry 2000, 55:481-504.

2. Havsteen $\mathrm{BH}$ : The biochemistry and medical significance of the flavonoids. Pharmacol Ther 2002, 96:67-202.

3. Patti A, Piatelli M, Nicolosi G: Use of Mucor miehe lipase in the preparation of long chain 3-Oacycatechins. J Mol Catal B Enzym 2000, 10:577-582.

4. Danieli B, Luisetti M, Sampognaro G, Carrea G, Riva S: Regioselective catalyzed by acylation of polyhydroxylated natural compounds Candida antarctic lipase B (Novozym 435) in organic solvents. J Mol Catal B Enzym 1997, 3:193-201.

5. Nakajima N, Ishihara K, Itoh T, Furuya T, Hamada H: Lipase-catalyzed direct and regioselective acylation of flavonoid glucoside for mechanistic investigation of stable plant pigments. J Biosci Bioeng 1999, 87:105-107.

6. Kontogianni A, Skouridou V, Sereti V, Stamatis H, Kolisis FN: Lipasecatalyzed esterification of rutin and naringin whit fatty acids of medium carbon chain. J Mol Catal B Enzym 2003, 21:59-62.

7. Riva S: Enzymatic modification of the sugar moieties of natural glycosides. J Mol Catal B Enzym 2002, 19-20:43-54.

8. Gupta MN: Enzyme function in organic solvents. Eur J Biochem 1992, 203:25-32.

9. Chebil L, Humeau C, Falcimaigne A, Engasser J, Ghoul M: Enzymatic acylation of flavonoids. Process Biochem 2006, 41:2237-2251.

10. Mellou F, Lazari D, Skaltsa H, Tselepis AD, Kolisis FN, Stamatis H: Biocatalytic preparation of acylated derivatives of flavonoid glycosides enhances their antioxidant and antimicrobial activity. J Biotechnol 2005, 116:295-304

11. Plou FJ, Cruces MA, Ferrer M, Fuentes G, Pastor E, Bernabé M, Christensen M, Comelles F, Parra JL, Ballesteros A: Enzymatic acylation of di- and trisaccharides with fatty acids: choosing the appropriate enzyme, support and solvent. J Biotechnol 2002, 16:55-66.

12. Ellaiah P, Prabhakar T, Ramakrishna B, Thaer Taleb A, Adinarayana K: Production of lipase by immobilized cells of Aspergillus nige. Process Biochem 2004, 39:525-528.

13. Silva VCF, Contesini FJ, Carvalho PO: Characterization and catalytic activity of free and immobilized lipase from Aspergillus nige: a comparative study. J Brazil Chem Soc 2008, 19(Suppl 8):1468-1474.

14. Jaeger KE, Reetz MT: Microbial lipases form versatile tools in biotechnology. Trends Biotechnol 1998, 16:396-403.

15. Jaeger K, Eggert T: Lipases for biotechnology. Curr Opin Biotechnol 2002, 13:390-397.

16. Chebil L, Anthoni J, Humeau C, Gerardin C, Engasser JM, Ghoul M: Enzymatic acylation of flavonoids: effect of the nature of the substrate, origin of lipase, and operating conditions on conversion yield and regioselectivity. J Agric Food Chem 2007, 55:9496-9502.

17. Gao C, Mayon P, MacManus DA, Vulfson EN: Novel enzymatic approach to the synthesis of flavonoid glycosides and their esters. Biotechnol Bioeng 2001, 71(Suppl 3):235-243.

18. Gayot S, Santarelli D, Coulon D: Modification of flavonoid using lipase in non-conventional media: effect of the water content. J Biotechnol 2003, 101:29-36. 
19. Shimoda K, Kubota N, Taniuchi K, Sato D, Nakajima N, Hamada H, Hamada $\mathrm{H}$ : Biotransformation of naringin by cultured Eucalyptus perriniana cells. Phytochemistry 2010, 71:201-205.

20. Otto R, Geers B, Weiss A, Petersohn D, Schlotmann K, Schröder KR: Novel Flavone Glycoside Derivatives for use in Cosmetics, Pharmaceuticals and Nutrition. US Pat 20030170186A1 2003, 11 [http://www.freepatentsonline. com/20030170186.pdf].

21. Passicos E, Santarelli X, Coulon D: Regioselective acylation of flavonoids catalyzed by immobilized Candida antarctica lipase under reduced pressure. Biotechnol Lett 2004, 26(Suppl 13):1073-1076.

22. Mellou F, Loutrari H, Stamatis H, Roussos C, Kolisis FN: Enzymatic esterification of flavonoids with unsaturated fatty acids: Effect of the novel esters on vascular endothelial growth factor release from K562 cells. Process Biochem 2006, 41(Suppl 9):2029-2034.

23. Peterson JJ, Dwyer JT, Beecher GR, Bhagwat SA, Gebhardt SE, Haytowitz DB, Holden JM: Flavanones in oranges, tangerines (mandarins), tangors, and tangelos: a compilation and review of the data from the analytical literature. J Food Compos Anal 2006, 19:566-s73.

24. Giannuzzo AN, Nazareno MA, Mishima HT, Mishima B: Extracción de naringina de Citrus paradisi L. estudio comparativo y optimización de técnicas extractivas. Cienc Tecnol Aliment 2000, 20(Suppl 2).

25. Fang $T$, Wang $Y$, Ma $Y$, Su W, Bai $Y$, Zhao P: A rapid LC/MS/MS quantitation assay for naringin and its two metabolites in rats plasma. $J$ Pharmaceut Biomed 2006, 40(Suppl 2):454-459.

26. Han SS, You IJ: Studies on antimicrobial activities and safety of natural naringin in Korea. Korean J Mycol 1988, 16:33-40.

27. Kaul TN, Middlenton J, Ogra PL: Antiviral effect of flavonoids on human viruses. J Med Virol 1985, 5:71-79.

28. Martín MJ, Marhuenda E, Pérez-Guerrero C, Franco JM: Antiulcer effect of naringin on gastric lesions induced by ethanol in rats. Pharmacology 1994, 49(Suppl 3):144-150.

29. So FV, Guthrie N, Chambers AF, Carroll KK: Inhibition of proliferation of estrogen receptor-positive MCF-7 human breast cancer cells by flavonoids in the presence and absence of excess estrogen. Cancer Lett 1997, 112(Suppl 2):127-133.

30. Bok SH, Shin YW, Bae KH, Jeong TS, Kwon YK, Park YB, Choi MS: Effects of naringin and lovastatin on plasma and hepatic lipids in high-fat and high-cholesterol fed rats. Nutr Res 2000, 20(Suppl 7):1007-1015.

31. Kim SH, Zo JH, Kim MA, Hwang KK, Chae IH, Kim HS, Kim CH, Sohn DW, $\mathrm{Oh}$ BH, Lee MM, Park YB: Naringin suppresses the mitogenic effect of lysophosphatidylcholine on vascular smooth muscle cells. Nutr Res 2003, 23:1671-1683.

32. Yang $H$, Henke $E$, Bornscheuer UT: The use of vinyl esters significantly enhanced enantioselectivities and reaction rates in lipase-catalyzed resolutions of aryl aliphatic carboxylic acids. J Org Chem 1999, 64:1709-1712.

33. Ardhaoui M, Falcimaigne A, Engassera JM, Moussoub P, Paulyb G, Ghoul M: Acylation of natural flavonoids using lipase of Candida antarctic as biocatalyst. J Mol Catal B Enzym 2004, 29(Suppl 16):63-67.

34. Viskuoicova J, Danihelova M, Ondrejovic M, Liptaj T, Sturdik E: Lipophilic rutin derivatives for antioxidant protection of oil-based foods. Food Chem 2010, 123(Suppl 1):45-50.

35. Moshkin VA: Castor New Delhi: Amerind; 1986.

36. Villeneuve P: Lipases in lipophilization reactions. Biotechnol Adv 2007, 25:515-536.

37. Trodler $P$, Pleiss J: Modeling structure and flexibility of Candida antarctica lipase B in organic solvents. BMC Struct Biol 2008, 8:9.

38. Arroyo M, Sánchez-Montero JM, Sinisterra JV: Thermal stabilization of immobilized lipase B from Candida antarctica on different supports: effect of water activity on enzymatic activity in organic media. Enzyme Microb Tech 1999, 24:3-12.

39. Solomons TWG, Fryhle C: Organic Chemistry. 9 edition. Hoboken, NJ: John Wiley \& Sons; 2007.

40. Marston A, Hostettmann K: Separation and Quantification of Flavonoids. In Flavonoids: chemistry, biochemistry, and applications. Edited by: Andersen OM, Markham KR. Boca Raton: Taylor 2006:

41. Schummera C, Delhommea O, Appenzellerb BMR, Wennigb R, Milleta M: Comparison of MTBSTFA and BSTFA next term in derivatization reactions of polar compounds prior to GC/MS analysis. Talanta 2009, 77(Suppl 4):1473-1482.
doi:10.1186/1752-153X-6-41

Cite this article as: Almeida et al:: Synthesis of naringin 6"-ricinoleate using immobilized lipase. Chemistry Central Journal 2012 6:41.

Publish with ChemistryCentral and every
scientist can read your work free of charge
"Open access provides opportunities to our
colleagues in other parts of the globe, by allowing
anyone to view the content free of charge."
W. Jeffery Hurst, The Hershey Company.
- available free of charge to the entire scientific community
- peer reviewed and published immediately upon acceptance
- yours - you keep the copyright
submit your manuscript here:
http://www.chemistrycentral.com/manuscript/

